\title{
Rancang Bangun Sistem Proteksi Kebocoran Pada Prototipe Mesin Reverse Osmosis Berbasis Mikrokontroler
}

\author{
Design of Leak Protection System in Microcontroller Based Reverse Osmosis Prototype
}

Rummi Santi Rama Sirait ${ }^{1}$, Muchlis Aulia ${ }^{2}$,

1,2,Fakultas Teknik, Universitas Budi Luhur

E-mail: ${ }^{1}$ rummi.sirait@budiluhur.ac.id, ${ }^{2}$ muchlisaulia27@gmail.com

\begin{abstract}
Abstrak
Penggunaan mesin reverse osmosis untuk memenuhi kebutuhan air layak minum dalam industri food and beverages adalah satu kesatuan yang tidak dapat dipisahkan. Salah satu permasalahan yang sering terjadi adalah kebocoran pada mesin tersebut. Pada penelitian ini dirancang sebuah alat rancang bangun sistem proteksi kebocoran prototipe mesin reverse osmosis berbasis mikrokontroler untuk mengurangi kerugian yang diakibatkan dari kebocoran. Proteksi kebocoran pada sistem menggunakan solenoid valve yang berfungsi mengatur buka atau tutup valve air. Sistem mendapat masukan dari sensor tekanan dan debit, sensor tersebut digunakan untuk menentukan apakah telah terjadi kebocoran. Keluaran yang dihasilkan berupa sinyal yang mengatur buka atau tutup solenoid valve dan mengirim pesan ke whatsapp bahwa telah terjadi kebocoran. Berdasarkan pengujian yang telah dilakukan sistem ini dapat memproteksi kebocoran dengan aktifnya solenoid valve (tutup) saat sistem mendeteksi kebocoran. Selisih debit air masuk dengan debit air keluar lebih dari $1 \mathrm{ml} / \mathrm{s}$ dan selisih tekanan air masuk dengan tekanan air keluar lebih dari $10 \mathrm{Kpa}$, maka sistem akan menganggap telah terjadi kebocoran. Semakin besar lubang kebocoran maka selisih tekanan air dan selisih debit air semakin besar. Sistem dapat mengirim pesan kebocoran ke whatsapp menggunakan komunikasi serial antara arduino mega2560 dengan pycharm IDE.
\end{abstract}

Kata kunci: Sensor Tekanan Air, Sensor Debit Air, Proteksi Kebocoran Air

\begin{abstract}
The use of reverse osmosis machines to meet the need for potable water in the food and beverages industry is an inseparable unit. One of the problems that often occurs is a leak in the machine. In this study, a microcontroller based reverse osmosis engine prototype leak protection system design tool was designed to reduce losses resulting from leaks. Leak protection in the system uses a solenoid valve which functions to regulate the opening or closing of the water valve. The system receives input from pressure and discharge sensors, the sensor is used to determine whether a leak has occurred. The resulting output is a signal that regulates the opening or closing of the solenoid valve and sends a message to WhatsApp that a leak has occurred. Based on the tests that have been done, this system can protect leaks by activating the solenoid valve (closed) when the system detects a leak. The difference between the inlet and the outflow water is more than $1 \mathrm{ml} /$ $s$ and the difference between the inlet and outlet water pressure is more than $10 \mathrm{Kpa}$, the system will assume a leak has occurred. The bigger the leakage hole, the greater the difference in water pressure and the difference in water discharge. The system can send leak messages to WhatsApp using serial communication between Arduino Mega2560 and Pycharm IDE.
\end{abstract}

Keywords: water pressure sensor, water discharge sensor, water leak protection 


\section{PENDAHULUAN}

Air merupakan sumber daya alam yang sangat penting terutama untuk kelangsungan kehidupan manusia. Pada dunia usaha food and beverage dalam memenuhi kebutuhan air yang siap untuk dikonsumsi menggunakan mesin reverse osmosis. Penggunaan mesin reverse osmosis pada industri food and beverages dipilih karena lebih efisien dibandingkan dengan membeli air galon isi ulang. Pemanfaatan teknologi membran reverse osmosis (RO) untuk mengolah air baku menjadi air siap minum (ARSINUM) saat ini sudah umum digunakan di berbagai negara. Membran RO mampu menghilangkan partikel dan ion dalam air umpan sehingga banyak digunakan untuk memurnikan air dan desalinasi[1]. Di era teknologi pada saat ini tersedia banyak berbagai jenis mesin reverse osmosis mulai dari untuk kebutuhan rumah tangga sampai kebutuhan food and beverage. Fokus mesin yang diambil saat ini adalah pada mesin reverse osmosis yang biasa digunakan pada dunia food and beverage. Kebocoran yang terjadi menyebabkan kerugian finansial yang cukup besar terlebih lagi jika kebocoran terjadi di malam hari, dimana pada saat itu tidak ada staf yang bertugas, sehingga akan membanjiri ruangan disekitar mesin reverse osmosis tersebut. Dalam mendeteksi kebocoran ini masih menggunakan kontak langsung yaitu dengan melihat kondisi mesin tersebut apakah ada tetesan atau genangan air di sekitar mesin reverse osmosis. Jelas cara ini sangat tidak efisien dikarenakan menunggu banjir disekitar mesin baru diketahui bahwa telah terjadi kebocoran pada mesin reverse osmosis tersebut.

Deteksi kebocoran pada mesin reverse osmosis sangat penting untuk mencegah kerugian yang ditimbulkan. Pada saat ini, banyak penelitian yang telah membahas cara mendeteksi kebocoran dan mengendalikan debit air. Penelitian yang dilakukan oleh [2] melakukan pengujian deteksi kebocoran pipa menggunakan teknologi Differential Pressure Transducer (DPT) yang ditempatkan sebelum dan sesudah titik kebocoran untuk merekam beda tekanan. DPT dihubungkan dengan peralatan pengkondisi sinyal dan ADC yang menghasilkan data beda tekanan. Dari penelitian tersebut diperoleh bahwa pada kondisi pipa bocor menghasilkan beda tekanan lebih tinggi dibandingkan kondisi pipa tidak bocor, kelemahan penelitian tersebut hanya untuk mendeteksi kebocoran pada pipa saja. Pada [3] menjelaskan tentang metode denoising adaptif berbasis VMD yang diterapkan pada jaringan pipa air bersih. Hasilnya metode tersebut dapat mengekstrak file komponen mode sinyal kebocoran dari gangguan, sehingga dapat meningkatkan kesalahan posisi kebocoran dibandingkan dengan metode denoising konvensional. Pada [4] menjelaskan tentang A Shazam-like household water leakage detection method, penelitian tersebut untuk mendeteksi kebocoran pada pipa rumah tangga menggunakan rekaman sinyal suara. Hasilnya sinyal suara yang diakibatkan dari kebocoran akan digunakan sebagai acuan bahwa telah terjadi kebocoran air.

Pada [5] menjelaskan A Novel location algorithm for pipeline leakage based on the attenuation of negative pressure wave untuk mendeteksi terjadinya kebocoran dengan menggunakan metode algortima novellocation. Hasilnya sistem dapat mendeteksi telah terjadi kebocoran dengan kesalahan terbesar $1,161 \%$ dan kesalahan terkecil sebesar 0,355 \%. Pada [6] menjelaskan Robust leakage detection and interval estimation of location in water distribution network, hasilnya pendeteksian kebocoran air menggunakan metode prorposed lebih akurat dan praktis untuk diterapkan serta menunjukkan presisi yang lebih tinggi. Pada [7] menjelaskan perancangan meter air menggunakan sensor aliran air SEN-HZ21WA. Hasilnya meter air yang dirancang dan meter air milik PDAM memiliki selisih rata-rata kesalahan pembacaan debit air 0,0181 liter/detik, tekanan air 0,1365 Bar, dan volume air 0,743 liter. Pada [8] menjelaskan purwarupa alat penyiram tanaman otomatis menggunakan sensor kelembaban tanah dengan notifikasi whatsapp. Hasilnya berupa notifikasi whatsapp pada setiap proses penyiraman dari alat penyiram tanaman otomatis. Pada [9] rancang bangun sistem pengukuran tekanan udara menggunakan DT-Sense Barometric Pressure Berbasis Internet of Things dengan tampilan pada smartphone. Hasilnya pengukuran dilakukan sebanyak 10 kali dengan pembacaan pada alat ukur standar konstan. Ketelitian rata-rata sistem yaitu 0.99 dengan standar deviasi rata-rata yaitu 0.7 dan kesalahan relatif rata-rata $0.0098 \%$. Pada [10] Studi kehilangan air akibat kebocoran pipa pada jalur distribusi PDAM Kota Magelang. Hasilnya persentase kehilangan air akibat kebocoran 
pipa di wilayah studi adalah sebesar 75,21\% di Armada Estate Utara; 43,97\% di Armada Estate Selatan; dan 25,33\% di Perumahan Depkes.

Berdasarkan penelitian-penelitian yang dilakukan sebelumnya, pendeteksian dan pengontrolan kebocoran air merupakan faktor penting dalam proses distribusi air. Pemilihan sensor yang sesuai juga berperan dalam mendeteksi kebocoran. Pada penelitian ini, penulis merancang pendeteksi kebocoran pada prototipe mesin reverse osmosis yang biasa digunakan pada industri food and beverages dengan prinsip otomatis. Metode yang digunakan adalah dengan menghitung perbedaan selisih besarnya nilai tekanan dan debit air pada air yang masuk dan keluar dari prototipe mesin reverse osmosis. Hasil yang pertama apabila terjadi kebocoran, solenoid valve air yang masuk ke prototipe mesin reverse osmosis akan menutup, serta sistem akan mengirim pesan ke whatsapp bahwa telah terjadi kebocoran pada prototipe mesin reverse osmosis tersebut. Hasil yang kedua adalah sistem mampu menampilkan besaran tekanan dan debit air yang masuk dan keluar pada prototipe mesin reverse osmosis di LCD 1, serta menampilkan jumlah pemakaian air prototipe reverse osmosis pada LCD 2.

\section{METODE PENELITIAN}

Perancangan sistem ini terdiri dari konsep kerja sistem, diagram blok keseluruhan, perancangan perangkat keras (hardware) dan perancangan perangkat lunak (software). Perancangan perangkat keras menjelaskan tentang tiap-tiap rangkaian elektronika serta pembuatan rangka alat secara keseluruhan, sedangkan perancangan perangkat lunak terdiri dari pembuatan algoritma dan flowchart program yang akan dimasukan pada mikrokontroler.

\subsection{Konsep Kerja Alat dan Sistem}

Konsep kerja sistem proteksi kebocoran prototipe mesin reverse osmosis berbasis mikrokontroler. Ketika semua komponen sudah dalam keadaan aktif, mikrokontroler akan mengontrol semua komponen yang terhubung dengan mikrokontroler tersebut. Terdapat dua sensor tekanan yang ditempatkan sebelum dan setelah prototipe mesin reverse osmosis. Kedua sensor tekanan tersebut berfungsi membaca berapa besar nilai tekanan air, dan terdapat dua sensor debit yang berfungsi membaca berapa debit air serta menghitung jumlah pemakaian air. Selanjutnya nilai tekanan dan debit air yang didapatkan akan dikirim ke pin masukan mikrokontroler untuk diproses. Mikrokontroler akan mengolah besar nilai tekanan air, nilai debit air dan besarnya pemakaian air untuk ditampilkan ke LCD, lalu menghitung berapa besar nilai selisih tekanan air sebelum dan setelah prototipe mesin reverse osmosis. Jika terjadi selisih melebihi batas normal maka sistem akan menganggap prototipe mesin reverse osmosis telah terjadi kebocoran. Untuk menambah tingkat keakuratan perhitungan selisih tekanan air, sensor debit juga digunakan sebagai sensor pendamping untuk memastikan terjadi kebocoran atau tidak. Hasil dari algoritma kontrol tesebut berupa sinyal keluaran yang akan digunakan untuk mengatur solenoid valve air yang masuk ke prototipe mesin reverse osmosis tersebut, ketika terjadi kebocoran solenoid valve akan on (tutup) serta sistem akan mengirim pesan ke whatsapp pengguna bahwa telah terjadi kebocoran.

\subsection{Diagram Blok Keseluruhan}

Diagram blok rancang bangun sistem proteksi kebocoran pada prototipe mesin reverse osmosis berbasis mikrokontroler ditunjukan pada Gambar 1. 


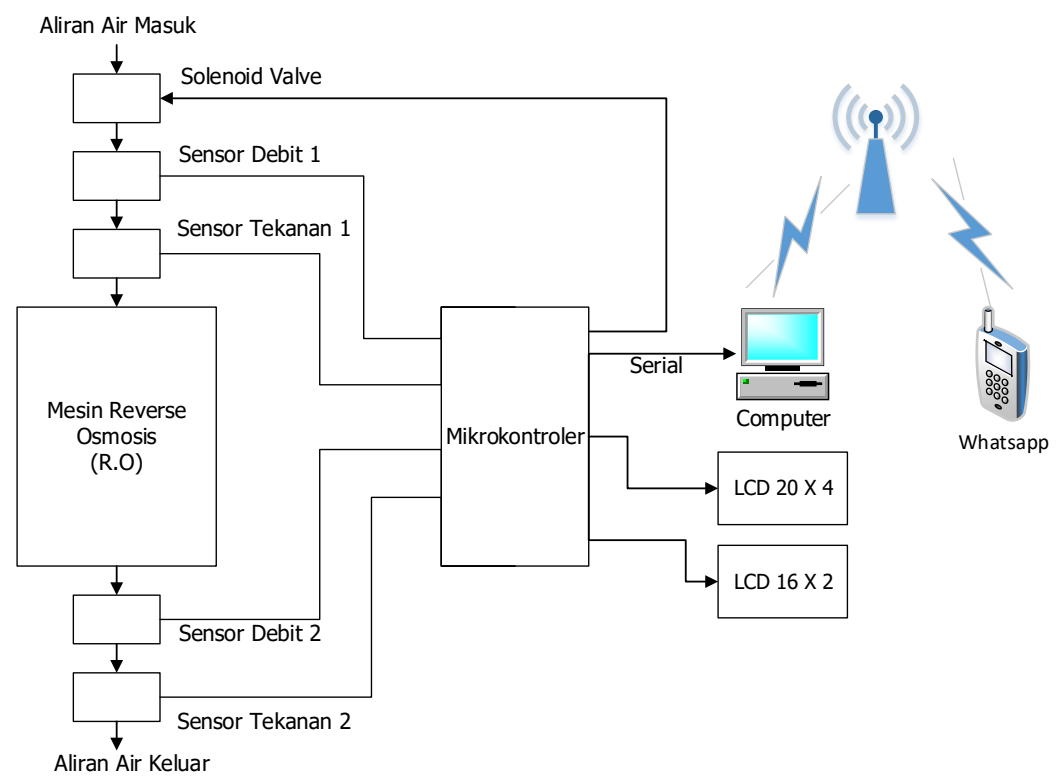

Gambar 1 Diagram Blok Keseluruhan

Keterangan Gambar 1 sebagai berikut :

1. Aliran Air Masuk $\quad$ : Air yang berasal dari air PDAM ataupun sumur bor yang akan di proses menjadi air layak konsumsi.

2. Aliran Air Keluar : Air yang telah melewati prototipe mesin reverse osmosis sehingga air yang keluar sudah layak untuk dikonsumsi.

3. Sensor Debit Air : Sebagai pembaca nilai debit air yang masuk dan keluar dari prototipe mesin reverse osmosis serta berfungsi membaca jumlah pemakaian air.

4. Sensor Tekanan Air : Sebagai pembaca nilai tekanan air yang masuk dan keluar dari prototipe mesin reverse osmosis.

5. Solenoid Valve : Sebagai valve otomatis bila sistem mendeteksi telah terjadi kebocoran maka katup solenoid akan menutup (off) sehingga kebocoran dapat teratasi.

6. LCD $16 \times 2$ : Sebagai layar yang akan menampilkan jumlah pemakaian air.

7. Arduino Mega 2560 : Pusat pengolahan dan kendali dari keseluruhan sistem yang diprogram, untuk membaca dan menerima inputan dari sensor dan mengeluarkan sinyal perintah untuk menggerakan katup solenoid valve dan mengirim pesan whatsapp ke pengguna saat terjadi kebocoran pada prototpe mesin reverse osmosis.

8. LCD $20 \times 4$

: Sebagai layar yang akan menampilkan nilai tekanan air dan debit air sebelum dan setelah prototipe mesin reverse osmosis.

9. Mesin R.O : Mesin yang dapat mengolah air baku yang bersumber dari PDAM maupun air tanah sehingga layak untuk dikonsumsi.

10. Serial : Sebagai penghubung komunikasi antara arduino mega2560 dengan laptop.

11. Komputer : Sebagai media pengirim pesan whatsapp kebocoran dengan bantuan aplikasi Pycharm IDE.

12. Whatsapp

: Aplikasi yang akan menerima pesan apabila sistem mendeteksi terjadinya kebocoran pada prototipe mesin reverse osmosis.

Pada Gambar 1 dapat dijelaskan bahwa sinyal masukan pertama adalah sinyal yang berasal dari pembacaan nilai tekanan dan nilai debit air yang masuk ke prototipe mesin reverse osmosis. 
Selanjutnya mikrokontroler akan melakukan algoritma kontrol untuk membandingkan besarnya nilai tekanan air yang masuk dengan nilai tekanan air yang keluar dari prototipe mesin reverse osmosis. Sensor debit air berfungsi sebagai pendamping sensor tekanan air agar tingkat akurasi dalam mendeteksi terjadinya kebocoran pada prototipe mesin reverse osmosis semakin baik serta berfungsi membaca jumlah pemakaian air. Nilai hasil pembacaan sensor tekanan dan sensor debit air akan ditampilkan di LCD 20 x 4, LCD 16 x 2 menampilkan jumlah pemakaian air. Kemudian variabel terkontrolnya adalah solenoid valve, yang mana solenoid valve ini berfungsi untuk menutup air yang masuk menuju prototipe mesin reverse osmosis jika sistem mendeteksi telah terjadi kebocoran serta sistem akan mengirim pesan whatsapp pemberitahuan ke pengguna bahwa telah terjadi kebocoran pada prototipe mesin reverse osmosis.

\subsection{Perancangan Sistem Mekanik dan Elektronik}

Sistem mekanik yang dirancang berupa kerangka besi sebagai penahan housing filter air dan sebagai dudukan pipa pvc, sensor tekanan air, sensor flow meter, LCD, dan Solenoid valve. Kerangka ini dibuat menggunakan besi siku dengan ketebalan $1.4 \mathrm{~mm}$ dan dimensi $60 \mathrm{~cm}$ x 50 $\mathrm{cm}$ x $30 \mathrm{~cm}$. Bentuk rancangan letak sensor dan solenoid valve ditunjukan pada Gambar 2.

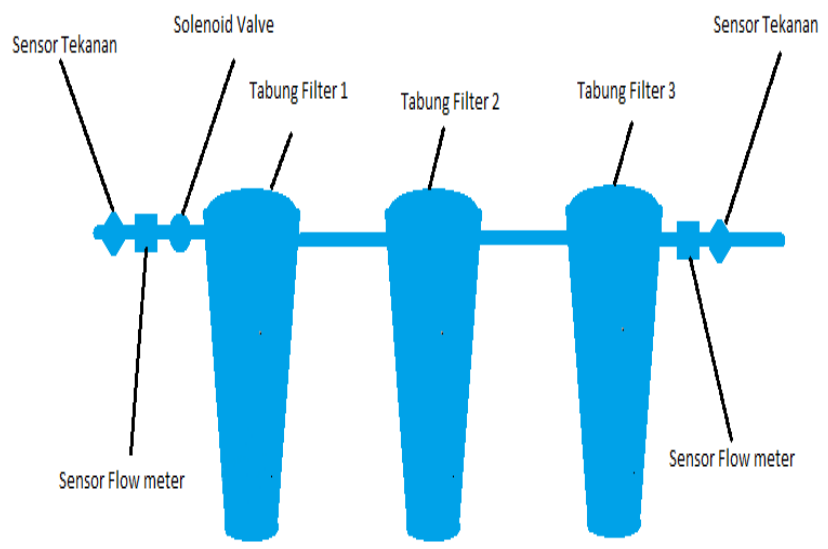

Gambar 2 Perancangan Letak Sensor

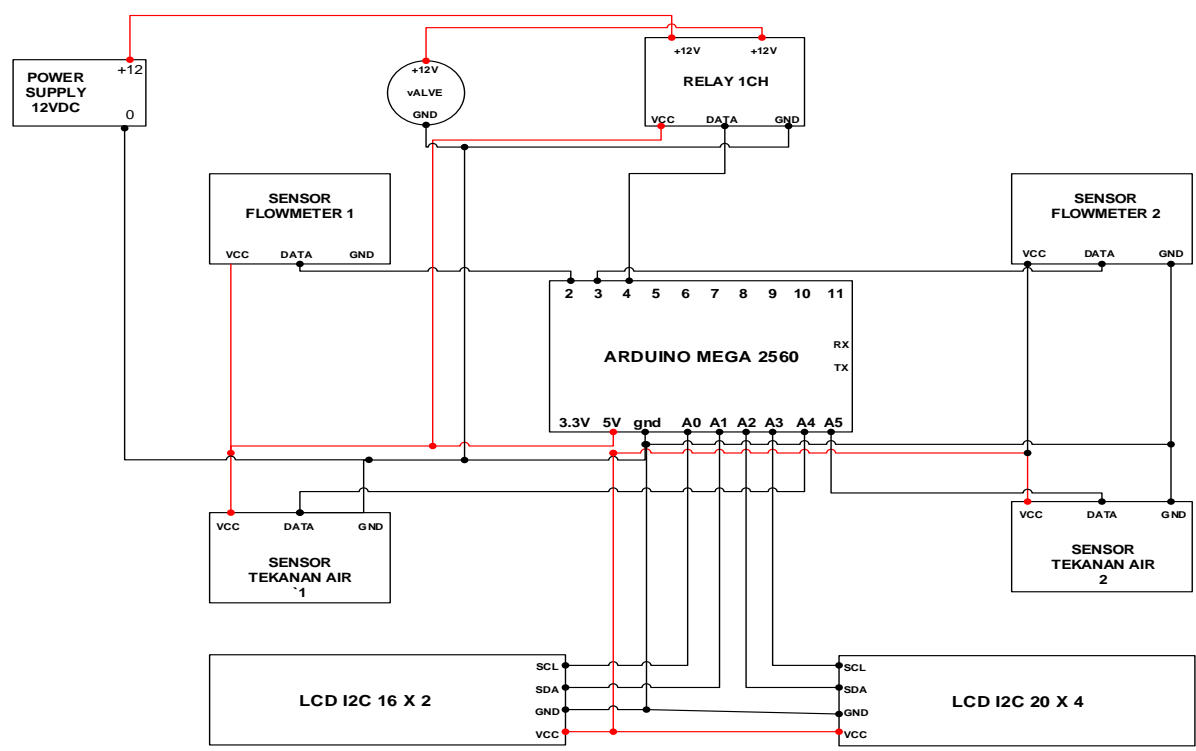

Gambar 3 Rangkaian Perancangan Rangkaian Elektronik

Perancangan rangkaian elektronik rancang bangun sistem proteksi kebocoran prototipe 
mesin reverse osmosis terdiri dari rangkaian mikrokontroler Arduino Mega2560, rangkaian sensor tekanan, rangkaian sensor flowmeter, rangkaian modul relay, rangkaian solenoid valve, dan 2 rangkaian LCD. Pada sistem ini menggunakan Arduino Mega2560 sebagai pengontrol utama dari sistem proteksi kebocorannya.

\subsection{Diagram Alir Sistem}

Diagram Alir rancang bangun sistem proteksi kebocoran prototipe mesin reverse osmosis menggunakan mikrokontroler ini menggunakan algoritma kontrol on-off atau if-then. Pada Gambar 4 dapat dijelaskan bahwa proses awal adalah menginisialisasikan variabel yang akan dimasukan kedalam program, kemudian dilakukan pembacaan sensor tekanan air sebelum dan setelah prototipe mesin reverse osmosis. Nilai tekanan dan debit air yang didapatkan akan ditampilkan pada LCD lengkap dengan data pemakaian air. Selanjutnya nilai tekanan dan nilai debit air yang didapatkan akan diolah oleh mikrokontroler untuk mendeteksi apakah terjadi kebocoran atau tidak. Jika terjadi kebocoran solenoid valve akan menutup dan mengirim pesan terjadi kebocoran ke whatsapp pengguna, dan sebaliknya bila tidak terjadi kebocoran maka solenoid valve tetap terbuka.

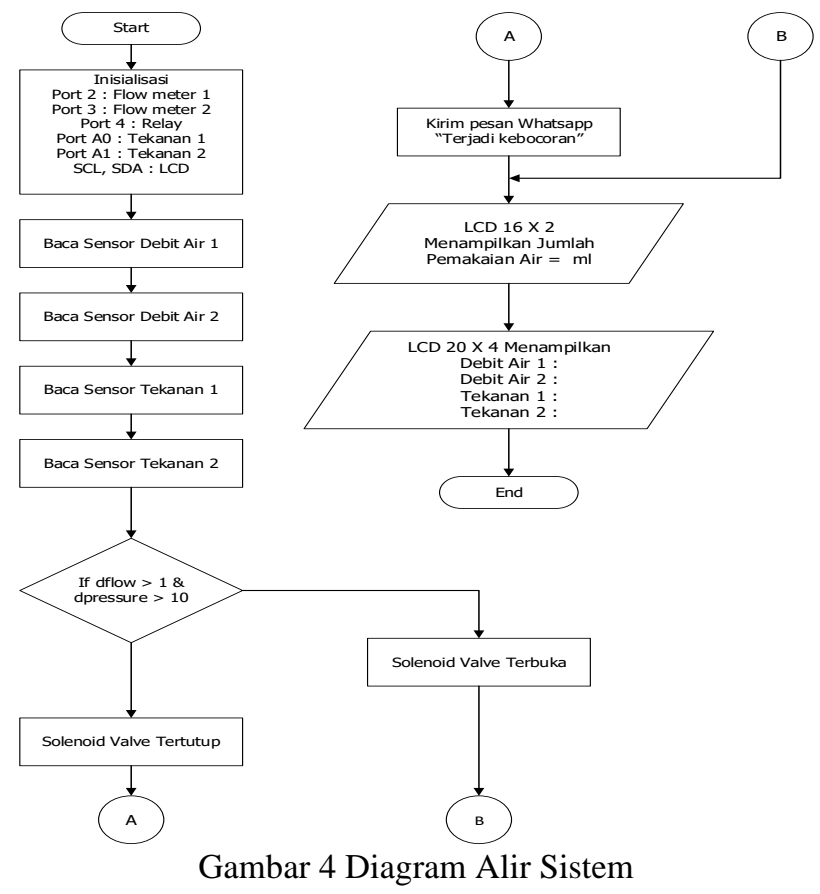

\section{HASIL DAN PEMBAHASAN}

Beberapa pengujian dilakukan dalam penelitian untuk mengetahui kinerja sistem secara keseluruhan. Pengujian kinerja sistem terdiri dari pengujian proteksi kebocoran otomatis dan pengujian sistem pengiriman pesan whatsapp saat terjadi kebocoran.

a. Hasil Rangkaian Alat Proteksi Kebocoran pada Prototipe Mesin Reverse Osmosis

Berdasarkan diagram blok rancangan perangkat mekanik, rangkaian alat proteksi kebocoran pada prototipe mesin reverse osmosis dapat dilihat pada Gambar 5. Rangkaian tersebut dihubungkan dengan sumber air. 


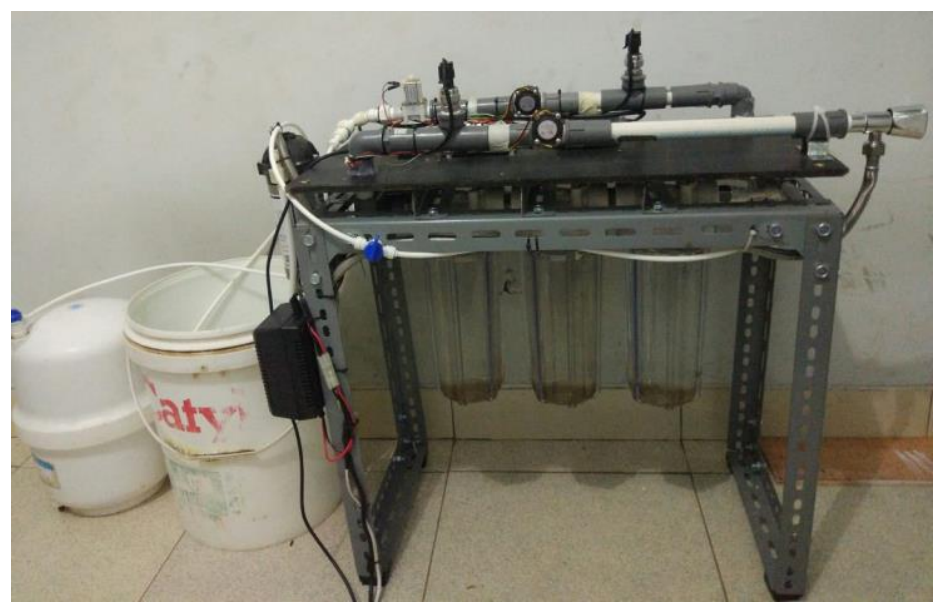

Gambar 5 Rangkaian Alat Proteksi Kebocoran pada Prototipe Mesin Reverse Osmosis

\section{b. Pengujian Sensor Debit Air}

Pengujian sensor debit air bertujuan untuk mengetahui tingkat akurasi pembacaan debit dan volume air yang melewati prototipe mesin reverse osmosis. Berdasarkan pengujian yang sudah dilakukan data yang didapatkan dapat dilihat pada Tabel 1, diperoleh rata-rata persentase kesalahan pembacaan sensor debit air senilai 5\%.

Tabel 1. Hasil Pengujian Sensor Debit Air

\begin{tabular}{|c|c|c|}
\hline Pengujian ke- & $\begin{array}{c}\text { Volume } \\
\text { Air terbaca gelas } \\
\text { ukur (ml) }\end{array}$ & $\begin{array}{c}\text { Volume air } \\
\text { terbaca sensor } \\
\text { debit (ml) }\end{array}$ \\
\hline Pengujian 1 & 100 & 93 \\
\hline Pengujian 2 & 100 & 99 \\
\hline Pengujian 3 & 100 & 109 \\
\hline Pengujian 4 & 100 & 106 \\
\hline Pengujian 5 & 100 & 102 \\
\hline
\end{tabular}

\section{c. Pengujian Sensor Tekanan Air}

Pengujian sensor tekanan air bertujuan untuk mengetahui tingkat akurasi pembacaan tekanan air yang masuk dan keluar dari prototipe mesin reverse osmosis. Berdasarkan pengujian yang sudah dilakukan data yang didapatkan dapat dilihat pada Tabel 2, diperoleh rata-rata persentase kesalahan pembacaan sensor tekanan air senilai $17,2 \%$.

Tabel 2. Hasil Pengujian Sensor Tekanan Air

\begin{tabular}{|c|c|c|}
\hline Pengujian ke- & $\begin{array}{c}\text { Pembacaan sensor } \\
\text { tekanan air } \\
\text { (bar) }\end{array}$ & $\begin{array}{c}\text { Tekanan air } \\
\text { sesungguhnya } \\
\text { (bar) }\end{array}$ \\
\hline Pengujian 1 & 1,9 & 2 \\
\hline Pengujian 2 & 2,6 & 2,5 \\
\hline Pengujian 3 & 3 & 3 \\
\hline Pengujian 4 & 3,3 & 3,5 \\
\hline Pengujian 5 & 4,1 & 4 \\
\hline
\end{tabular}

\section{d. Pengujian Solenoid Valve}

Pengujian solenoid valve bertujuan untuk mengetahui status solenoid valve (buka/tutup) ketika mendapatkan sinyal masukan dari sistem bila terjadi kebocoran, serta memastikan solenoid valve berfungsi menutup aliran air yang masuk ke prototipe mesin reverse osmosis. Berdasarkan hasil pengujian solenoid valve yang telah dilakukan sebanyak 5 kali dapat dilihat pada Tabel 3, maka dapat disimpulkan solenoid valve berfungsi dengan baik dapat menutup aliran air pada saat diberi tegangan $12 \mathrm{vdc}$, dan dapat mengalirkan air saat tidak ada teganganan 12vdc. 
Tabel 3. Hasil Pengujian Solenoid Valve

\begin{tabular}{|c|c|c|c|}
\hline Pengujian Ke- & $\begin{array}{c}\text { Status Solenoid } \\
\text { Valve }\end{array}$ & $\begin{array}{c}\text { Tegangan pada } \\
\text { koil } \\
(\mathrm{vdc})\end{array}$ & $\begin{array}{c}\text { Aliran air pada } \\
\text { solenoid valve }\end{array}$ \\
\hline Pengujian 1 & Tutup & 12,85 & Tidak mengalir \\
\hline Pengujian 2 & Buka & 0 & Mengalir \\
\hline Pengujian 3 & Tutup & 12,86 & Tidak mengalir \\
\hline Pengujian 4 & Buka & 0 & Mengalir \\
\hline Pengujian 5 & Tutup & 12,85 & Tidak mengalir \\
\hline
\end{tabular}

\subsection{Pengujian Sistem Proteksi Kebocoran}

Pengujian keseluruhan ini adalah pengujian sistem proteksi kebocoran air pada prototipe mesin reverse osmosis untuk dapat menghentikan aliran air yang menuju ke mesin tersebut saat terjadi kebocoran. Supaya kebocoran tersebut dapat terproteksi secepatnya, sehingga mengurangi kerugian yang diakibatkan dari kebocoran tersebut. Sistem akan mengirim pesan whatsapp ke pengguna bahwa telah terjadi kebocoran pada mesin prototipe reverse osmosis tersebut. Pengujian sistem dilakukan dalam 2 kondisi kebocoran yang berbeda yaitu kondisi pertama prototipe mesin reverse osmosis sedang ada pemakaian air, kondisi kedua prototipe mesin reverse osmosis tidak ada pemakaian air. Simulasi kebocoran dilakukan dengan membuat 3 lubang kebocoran dengan diameter yang berbeda, dan tiap lubang dilakukan pengujian sebanyak 5 kali, tiap pengujian kebocoran akan dibiarkan selama 1 menit untuk mengetahui volume air yang terbuang. Tabel 4 menunjukkan hasil pengujian sistem saat tidak ada pemakaian air. Tabel 5 menunjukkan hasil pengujian sistem saat sedang ada pemakaian air.

Tabel 4 Hasil Pengujian Sistem Proteksi Kebocoran Saat Tidak Ada Pemakaian Air

\begin{tabular}{|c|c|c|c|c|c|}
\hline \multirow[b]{2}{*}{$\begin{array}{l}\text { Pengujian } \\
\quad \text { ke - }\end{array}$} & \multicolumn{3}{|c|}{$\begin{array}{l}\text { Volume air yang terbuang selama } \\
11 \text { menit }\end{array}$} & \multirow{2}{*}{$\begin{array}{l}\text { Status } \\
\text { solenoid } \\
\text { valve }\end{array}$} & \multirow[b]{2}{*}{ Keterangan } \\
\hline & $\begin{array}{c}\text { Diamater } \\
\text { lubang } 4 \\
\text { mm }\end{array}$ & $\begin{array}{c}\text { Diameter } \\
\text { lubang } 6 \\
\mathrm{~mm}\end{array}$ & $\begin{array}{c}\text { Diameter } \\
\text { lubang } 8 \\
\mathrm{~mm}\end{array}$ & & \\
\hline 1 & 0 & 0 & 0 & Buka & Normal \\
\hline 2 & $2,8 \mathrm{~L}$ & $4,4 \mathrm{~L}$ & $5,6 \mathrm{~L}$ & Tutup & Bocor \\
\hline 3 & $2,7 \mathrm{~L}$ & $4,3 \mathrm{~L}$ & $5,6 \mathrm{~L}$ & Tutup & Bocor \\
\hline 4 & $2,8 \mathrm{~L}$ & $4,4 \mathrm{~L}$ & $5,6 \mathrm{~L}$ & Tutup & Bocor \\
\hline 5 & $2,8 \mathrm{~L}$ & $4,4 \mathrm{~L}$ & $5,7 \mathrm{~L}$ & Tutup & Bocor \\
\hline 6 & $2,8 \mathrm{~L}$ & $4,4 \mathrm{~L}$ & $5,7 \mathrm{~L}$ & Tutup & Bocor \\
\hline
\end{tabular}

Berdasarkan hasil pengujian pada Tabel 4 dapat dilihat sistem proteksi kebocoran dapat berfungsi sesuai dengan sistem yang dirancang. Pada saat sistem mendeteksi telah terjadi kebocoran maka solenoid valve air yang masuk ke prototipe mesin reverse osmosis akan menutup dan ketika lubang kebocoran ditutup maka solenoid valve air akan kembali terbuka.

Tabel 5 Hasil Pengujian Sistem Proteksi Kebocoran Saat Ada Pemakaian Air

\begin{tabular}{|c|c|c|c|c|c|}
\hline \multirow[b]{2}{*}{$\begin{array}{l}\text { Pengujian } \\
\text { ke - }\end{array}$} & \multicolumn{3}{|c|}{$\begin{array}{l}\text { Volume air yang terbuang selama } \\
\qquad 1 \text { menit }\end{array}$} & \multirow{2}{*}{$\begin{array}{c}\text { Status } \\
\text { solenoid } \\
\text { valve }\end{array}$} & \multirow[b]{2}{*}{ Keterangan } \\
\hline & $\begin{array}{c}\text { Diamater } \\
\text { lubang } 4 \\
\mathrm{~mm}\end{array}$ & $\begin{array}{c}\text { Diameter } \\
\text { lubang } 6 \\
\mathrm{~mm}\end{array}$ & $\begin{array}{c}\text { Diameter } \\
\text { lubang } 8 \\
\text { mm }\end{array}$ & & \\
\hline 1 & 0 & 0 & 0 & Buka & Normal \\
\hline 2 & $1,3 \mathrm{~L}$ & $1,8 \mathrm{~L}$ & $2,4 \mathrm{~L}$ & Tutup & Bocor \\
\hline 3 & $1,4 \mathrm{~L}$ & $1,8 \mathrm{~L}$ & $2,2 \mathrm{~L}$ & Tutup & Bocor \\
\hline 4 & $1,3 \mathrm{~L}$ & $1,9 \mathrm{~L}$ & $2,4 \mathrm{~L}$ & Tutup & Bocor \\
\hline 5 & $1,3 \mathrm{~L}$ & $1,8 \mathrm{~L}$ & $2,4 \mathrm{~L}$ & Tutup & Bocor \\
\hline 6 & $1,3 \mathrm{~L}$ & $1,8 \mathrm{~L}$ & $2,4 \mathrm{~L}$ & Tutup & Bocor \\
\hline
\end{tabular}

Berdasarkan hasil pengujian pada Tabel 5 dapat dilihat sistem proteksi kebocoran dapat berfungsi sesuai dengan sistem yang telah dirancang. Pada saat sistem mendeteksi telah terjadi 
kebocoran maka solenoid valve air yang masuk ke prototipe mesin reverse osmosis akan menutup, dan ketika lubang kebocoran ditutup maka solenoid valve air akan kembali terbuka. Total volume air yang terbuang akibat dari kebocoran pada Tabel 4 ini lebih sedikit bila dibandingkan dengan Tabel 5 dikarenakan pengujian sistem proteksi kebocoran pada Tabel 5 dilakukan pada saat prototipe mesin reverse osmosis tersebut ada pemakaian (kran keluaran posisi terbuka).

Pada saat terjadi kebocoran sistem akan mengirim pesan ke whatsapp pengguna bahwa telah terjadi kebocoran. Berikut foto pesan whatsapp yang telah terkirim pada saat sistem mendeteksi telah terjadi kebocoran.

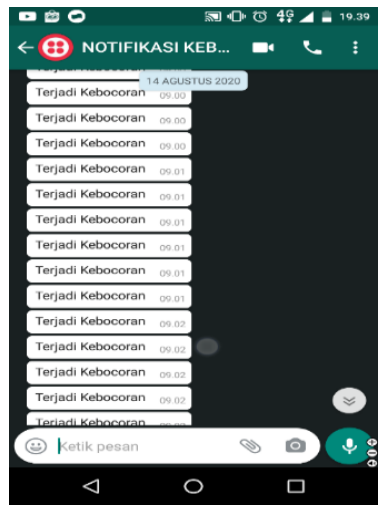

Gambar 6 Pesan Whatsapp Kebocoran

\section{KESIMPULAN DAN SARAN}

Berdasarkan hasil pengujian yang telah dilakukan, terdapat beberapa hal yang dapat disimpulkan yakni sebagai berikut.

1. Selisih tekanan masuk dengan tekanan keluar adalah lebih dari $10 \mathrm{Kpa}$ pada saat terjadi kebocoran, karena pada saat tidak terjadi kebocoran sudah mengalami selisih $\pm 8 \mathrm{Kpa}$.

2. Selisih debit masuk dengan debit keluar pada saat terjadi kebocoran adalah lebih dari $1 \mathrm{ml} / \mathrm{s}$, berbeda dengan sensor tekanan yang mengalami selisih walaupun tidak mengalami kebocoran. Sensor debit mengalami selisih saat terjadi kebocoran saja.

3. Pada saat terjadi kebocoran sistem merespon dengan mengaktifkan solenoid valve sehingga aliran air yang menuju ke mesin prototipe reverse osmosis berhenti, sehingga kebocoran dapat teratasi.

4. Sistem dapat mengirim pesan ke whatsapp pengguna saat terjadi kebocoran menggunakan komunikasi serial.

\section{DAFTAR PUSTAKA}

[1] J. Prayitno, "Aspek Mikrobiologi Dalam Pengolahan Air Siap Minum Menggunakan Membran Reverse Osmosis," J. Rekayasa Lingkung., vol. 12, no. 2, pp. 175-184, 2020.

[2] B. Santoso and T. S. Widodo, "Deteksi Kebocoran Pipa Pada Aliran Dua Fase Plug Menggunakan Analisis Fluktuasi Beda Tekanan," J. Energi Dan Manufaktur, vol. 6, no. 1, pp. 1-8, 2014.

[3] J. Li, Y. Chen, Z. Qian, and C. Lu, "Research on VMD based adaptive denoising method applied to water supply pipeline leakage location," Meas. J. Int. Meas. Confed., vol. 151, p. 107153, 2020.

[4] S. Seyoum, L. Alfonso, S. Jan, V. Andel, W. Koole, and N. Van De Giesen, "A Shazamlike household water leakage detection method," Procedia Eng., vol. 186, pp. 452-459, 
2017.

[5] J. Li, Q. Zheng, Z. Qian, and X. Yang, "A novel location algorithm for pipeline leakage based on the attenuation of negative pressure wave," Process Saf. Environ. Prot., vol. 123, pp. 309-316, 2019.

[6] Y. Kim, S. J. Lee, T. Park, G. Lee, J. C. Suh, and J. M. Lee, "Robust leakage detection and interval estimation of location in water distribution network," IFAC-PapersOnLine, vol. 28, no. 8, pp. 1264-1269, 2015.

[7] R. Wiryadinata and B. F. Butar-butar, "Rancang Bangun Alat Meteran Air Digital Menggunakan Sensor Aliran Air SEN-HZ21WA," VOLT J. Ilm. Pendidik. Tek. Elektro, vol. 3, no. 1, p. 26, 2018.

[8] F. Hidayat, "Purwarupa Alat Penyiram Tanaman Otomatis menggunakan Sensor Kelembaban Tanah dengan Notifikasi Whatsapp," Pros. Semnastek, no. iv, pp. 1-2, 2019.

[9] I. Tri Handini, Y. Yulkifi, and Y. Darvina, "Rancang Bangun Sistem Pengukuran Tekanan Udara Menggunakan DT-Sense Barometric Pressure Berbasis Internet of Things dengan Display Smartphone," J. Teor. dan Apl. Fis., vol. 8, no. 1, pp. 1-10, 2020.

[10] D. Nugraha, "Studi Kehilangan Air Akibat Kebocoran Pipa Pada Jalur Distribusi Pdam Kota Magelang (Studi Kasus: Perumahan Armada Estate Dan Depkes, Kramat Utara Kecamatan Magelang Utara )," J. Presipitasi, vol. 7, no. 2, pp. 71-76-76, 2010. 